\title{
Gender and Speech in a Disney Princess Movie
}

\author{
Azmi, N.J. (Corresponding author) \\ Faculty of Languages and Communication, Universiti Sultan Zainal Abidin 21300 Kuala Terengganu Malaysia \\ E-mail: jijidianaazmi@unisza.edu.my \\ Radzuwan Ab Rashid \\ Faculty of Languages and Communication, Universiti Sultan Zainal Abidin 21300 Kuala Terengganu Malaysia \\ E-mail: radzuwanrashid@unisza.edu.my \\ Mairas Abd. Rahman \\ Faculty of Languages and Communication, Universiti Sultan Zainal Abidin 21300 Kuala Terengganu Malaysia \\ E-mail: mairas@unisza.edu.my \\ Safawati Basirah, Z \\ Faculty of Languages and Communication, Universiti Sultan Zainal Abidin 21300 Kuala Terengganu Malaysia \\ E-mail: safawatibasirah@unisza.edu.my
}

Received: 18-06-2016 Accepted: 25-08-2016

Advance Access Published: September 2016

Published: 01-11-2016 doi:10.7575/aiac.ijalel.v.5n.6p.235 URL: http://dx.doi.org/10.7575/aiac.ijalel.v.5n.6p.235

\begin{abstract}
One of the latest Disney princess movies is Frozen which was released in 2013. Female characters in Frozen differ from the female characters in previous Disney movies, such as The Little Mermaid and Tangled. In comparison, female characters in Frozen are portrayed as having more heroic values and norms, which makes it interesting to examine their speech characteristics. Do they use typical female speech despite having more heroic characteristics? This paper aims to provide insights into the female speech characteristics in this movie based on Lakoff's (1975) model of female speech. Data analysis shows that female and male characters in the movie used almost equal number of female speech elements in their dialogues. Interestingly, although female characters in the movie do not behave stereotypically, their speech still contain the elements of female speech, such as the use empty adjectives, questions, hedges and intensifier. This paper argues that the blurring of boundaries between male and female speech characteristics in this movie is an attempt to break gender stereotyping by showing that female characters share similar characteristics with heroic male characters thus they should not be seen as inferior to the male characters.
\end{abstract}

Keywords: Disney princess, Frozen, linguistic, movie, speech, gender studies

\section{Introduction}

Disney princess movies are well-known all over the world and has become part of popular culture. Girls of all generations grow up watching these movies in their childhood. Children are prone to follow the gender characteristics portrayed in their favourite movies. As argued by Witt (2000), children have high tendency to copy the female characteristics in the movies that they watch because they believe that it is an acceptable way of behaving. Children movies also help the children to learn and develop their language in a friendlier manner compared to the learning in formal setting. This is because children will be more comfortable to learn language due to the presence of interesting characters and visual effects. Ismail \& Yusof (2016) state that among the effective ways for children to learn language is by incorporating informal materials in their learning, such as storybooks with pictures and narrated in local setting and culture.

Disney princess movies are suitable to be used as learning materials as the animation is especially designed to suit children's interest where important messages are conveyed through exciting characters and songs. The movies have high and powerful influence on young girls all over the world (Lacroix, 2004). The plot of earlier Disney movies revolves around saving female characters from villains and searching for a new start in their life after they undergo major crisis. However, the plot and theme shift to the chasing of dreams and being independent in more recent Disney princess movies.

The aim of this study is to investigate the speech characteristics of the female characters in 2013 Frozen and to identify whether the characters use gendered language in their dialogues. The new generation of Disney princesses are portrayed as more adventurous, brave, independent and strong-willed (Law, 2014; Saladino, 2014; Chaney, 
2012). It is interesting to examine whether their characteristics which break the stereotype of female characters match their language characteristics.

\section{Gender portrayal in Disney movies}

Gender roles have been studied by several researchers across disciplines since many years ago. Men and women are often characterized based on their roles (Skorek \& Schreier, 2009). Representations of men and women always differ. Men are often portrayed as masculine, strong and independent while women are portrayed as feminine, graceful and gentle.

Gender portrayal in Disney movies can be categorized into three main eras. The first era is the first generation of Disney princess which includes three movies: Snow White and the Seven Dwarves (1938), Cinderella and Sleeping Beauty. The female characters in these movies are Snow White, Cinderella and Aurora. These characters share similar characteristics. They are gentle, soft-spoken, dutiful and beautiful. They also portray the least amount of independence, rely on the male characters to achieve their dreams and have lack of power.

The second era is the second generation of Disney princess movies. Although there are some similar traits in the second generation movies with the first generation movies, the characters in the second generation are reinvented by the Disney production. The female characters are more independent, they strive to achieve their dreams, and they show some power or control in their characters. However, the female characters still retain gender stereotype because at the end of the movie, the female characters do not perform final rescue without the involvement of the male characters (England, Descartes, \& Melissa, 2011). Some examples of second generation Disney movies are The Little Mermaid (1989), Beauty and the Beast (1991), Pocahontas (1995) and Mulan (1998).

The third era of Disney princess movies are the ones presented to the third generation, such as Princess and the Frog (2009), Tangled (2010), Brave (2012) and Frozen (2013). The characters in these movies are Tiana, Rapunzel, Merida, and Anna and Elsa. They are very independent characters, and are not portrayed as being gracious and gentle, unlike the first generation characters. They are brave and pursue their dreams with minimum help from the male characters. They are strong-willed, adventurous and bold. Rome (2010) highlights that the characters in the Disney princesses' third generation movies attempt to break the norms where they show strong, powerful and ambitious characteristics.

Tiana from the Princess and the Frog is portrayed as an independent woman who works to achieve her dream to have her own restaurant. She works hard days and nights and does not rely on other characters to achieve the dream. Even though she falls in love with Prince Navin, the male character in the movie, she does not rely on him. Instead, it is the prince who relies on her to get him out of troubles.

Rapunzel from Tangled is also portrayed as a strong lady. She saves Flynn Rider, the male character in the pub from a group of thugs. She is able to climb a wall and tress, and adventurous too. She even saves Flynn Rider's life with the magical power she has.

Merida from Brave really comes out of the norms when she boldly wants to change her fate and is not afraid to voice out her opinion (Saladino, 2014). She seldom and almost never questions herself and her decision. She takes responsibility of her actions and is not afraid to say that she is wrong.

Finally, Elsa and Anna are two characters from Frozen. Elsa is strong and powerful because she rules a kingdom. Although she has the biggest fear in her life, she finally manages to overcome her fear and rules her kingdom and is adored by her subjects. Anna on the other hand is fearless and outspoken. She is not afraid to voice out her thought. She is brave and adventurous. Anna is portrayed as someone who has physical strength (Law, 2014), and this is out of the norm of first generation or typical Disney princesses' character. For example, she fights Mashmallow, the big scary ice monster, who tries to harm her and friends. At the end of the movie, Anna slaps Hans as a punishment for his betrayal towards her, her sister-Elsa and her kingdom-Arandelle. Although male characters are visible in both scenes, Anna shows her bravery and fights the monster and Hans.

The evolution and changes in the characteristic of the Disney princesses are influenced by the cultural and society's view towards gender role during the production era. Heritage (2015) points out that the Walt Disney Company has to comply with wider target audience and the characteristics of the languages used must be suitable with the societal temporal condition.

\section{Characteristics of speech}

Kramer (1975) puts forth that certain traits of qualities or characteristics of an individual can be seen non-verbally and verbally. A person shows their personality or characteristic through their actions, but most of the time their personality or characteristics can be identified through their speech (ibid). Stereotypical gender-role quality, such as aggressive, emotional, objective, dominant, and self-confident can be recognized through speech and conversation.

Male and female conversations also differ in characteristics. Lakoff (1975) states that women use more empty adjectives compared to men. Women show their affection, friendliness and kindness through their speech. Women speech is also associated with politeness, softness and gentleness, whereby men speech or conversations are associated with power, firmness and formality. 
However, this is not quite significant in today's cultural background and scenario. In post-feminism era, men and women are striving for similarity and the characteristics of speech used by men and women are also changing.

\section{Research Design}

One Disney movie was selected as the primary source for this research, that is, Frozen which was produced in 2013. Thirty two scenes were selected from the movie for the analysis. These scenes were selected because they have balanced female and male dialogues. The dialogues were transcribed accordingly and analysed based on the Lakoff's (1975) model of female speech characteristics.

Six characters were selected for the analysis: Queen Elsa (Female), Princess Anna (Female), Kristoff (Male), Prince Han (Male), Oakley (Male) and Duke of Weselton (Male). Other characters, such as Olaf the Snowman, Pabbie and Sven were not included because they are not human characters. The movie was watched three times. The first watch was to identify the characters and the plot of the movies. The second watch was for the purpose of transcribing the dialogues and the third watch was to ensure the dialogues were transcribed correctly. The characteristics were then coded in the coding sheets so that the frequency of the utterances can be recorded and identified. Content analysis was conducted in order to identify the words or terms that fit into the theme or characteristics being studied.

\section{Analysis and Discussion}

This section discusses four characteristics of female speech as proposed by Lakoff (1975). The definition and findings for each characteristic are presented below.

\subsection{Empty Adjective}

Empty adjectives refer to certain types of exclamation that are typical to female speech and acceptable in the society but do not have any meaning (Lakoff, 1975). For instance, the terms such as "Oh dear", "Oh, lovely" or "Wonderful" are acceptable in the society as representing female speech. These are the examples of empty adjectives that suit female speech because they represent politeness, softness and courtesy (ibid). In the movie, there are balanced empty adjectives among the female and male characters. The frequency of empty adjectives that were uttered by the characters in Frozen is as follow:

Table 1. Frequency of empty adjectives used by the characters

\begin{tabular}{lc}
\hline \multicolumn{1}{c}{ Character } & Frequency of empty adjective \\
\hline Princess Anna & 7 \\
\hline Queen Elsa & 2 \\
\hline Kristoff & 6 \\
\hline Prince Han & 0 \\
\hline Oakley & 1 \\
\hline Duke of Weselton & 0 \\
\hline
\end{tabular}

Extract 1

Princess Anna : Yeah, the whole thing! You got it. Okay, wait, wait. So you have how many brothers?

Prince Han : Twelve older brothers. Three of them pretended I was invisible - literally - for two years.

Princess Anna : That's horrible. (Empty adjective).

Extract 1 shows that the female character used empty adjective 'that's horrible' to show her sympathy towards the male character. Instead of saying the words 'sympathy', the female character used empty adjective to represent her feeling in a more polite way.

Extract 2

Kristoff : Forty? No, ten.

Oaken : Oh dear (empty adjective), that's no good. See, these are from our winter stock, where supply and demand have a big problem.

Extract 2 on the other hand is the conversation between two male characters. Oaken used empty adjective 'Oh dear' that is normally used in female conversation. In this context, female empty adjective is used by the male character for the politeness in the conversation, as the two characters are strangers and they want to maintain the politeness and respect toward each other. 
5.2 Hedges

Hedges refer to words or phrases that represent uncertainty (Lakoff, 1975). Although hedges are popular in female conversation, men use many hedges in their conversation too. This can be seen in several studies, such as Rashid, Rahman and Rahman (2016). Analysis on the hedges used in Frozen also shows that both male and female characters use hedges when they are uncertain.

Some example of hedges used are 'well', 'kind of', 'sort of', 'I think so', and 'you know'. The frequency of hedges used by the characters in Frozen is as follows:

Table 2. Frequency of hedges used by the characters

\begin{tabular}{ll}
\hline \multicolumn{1}{c}{ Character } & Frequency of hedges \\
\hline Princess Anna & 7 \\
\hline Queen Elsa & 1 \\
\hline Kristoff & 3 \\
\hline Prince Han & 0 \\
\hline Oakley & 0 \\
\hline Duke of Weselton & 0 \\
\hline
\end{tabular}

Extract 3

Duke : Let me know when you're ready for the next round, My Lady.

Queen Elsa : Well (Hedges), he was sprightly.

\subsection{Intensifier}

The next female speech characteristic examined in this study is the use of intensifier. Lakoff (1975) defines intensifier as a word that is used to add force or to boost the meaning of other adjectives, verb or adverbs. The examples of intensifier are "extremely", "strongly", and "truly". Women usually use intensifier in their conversation, as it adds more dramatic meaning to the adjective, verbs or adverbs that are being described or mentioned by them (Rashid et al., 2016; Rashid, 2016). The frequency of intensifier produced by the characters in Frozen is as follows:

Table 3. Frequency of intensifier used by the characters

\begin{tabular}{ll}
\hline \multicolumn{1}{c}{ Character } & Frequency of intensifier \\
\hline Princess Anna & 1 \\
\hline Queen Elsa & 0 \\
\hline Kristoff & 1 \\
\hline Prince Han & 1 \\
\hline Oakley & 0 \\
\hline Duke of Weselton & 1 \\
\hline
\end{tabular}

\subsection{Questions}

Questions refer to the statements that are used to ask questions. Lakoff (1975) states that women use more questions than man because of their insecurities. Women ask questions more often even when explanation or declaration have been made to clarify certain case or issue. However, in the movie, male and female characters use equal number of questions in their dialogues.

Table 4. Frequency of question used by the characters

\begin{tabular}{lc}
\hline \multicolumn{1}{c}{ Character } & Frequency of question \\
\hline Princess Anna & 39 \\
\hline Queen Elsa & 15 \\
\hline Kristoff & 30 \\
\hline Prince Hans & 5 \\
\hline Oakley & 3 \\
\hline Duke of Weselton & 8 \\
\hline
\end{tabular}


The female characters in Frozen, especially Princess Anna, uttered the most questions in the movie. There are times when she used questions to seek approval. There are also times when she used questions for uncertainty and affirmation. Kristoff the male characters also used many questions in the conversation but most of the time, Kristoff used questions to find answers for the information beyond his knowledge.

Extract 4:

Anna : Elsa, please, please. I can't live like this anymore.

Elsa : Then leave.

Anna : What did I ever do to you? [Questions]

Elsa : Enough, Anna.

Anna : No! Why? [Questions]. Why do you shut me out?! [Question] Why do you shut the world out?! [Question]. What are you so afraid of?! [Question]

Extract 8 shows that Anna asked continuous questions when she confronted her sisters and forced her to explain the reason of her actions. Continuous questions were asked by Anna without waiting for the answer from her sister, Elsa. In short, the female characters used questions in their conversation when they are uncertain, and to seek answer and explanation on certain issues.

\section{Conclusion}

The aim of this study is to investigate the speech characteristics of the characters in Disney princess movie, Frozen. The dialogues were coded based on Lakoff's (1975) model of speech characteristics which consist of: empty adjectives, hedges, intensifier and questions. Data analysis shows that the most used speech characteristic in the movie is Questions. All characters in the movies asked questions in their dialogues and the character that uttered the most questions is Anna, the female character. Empty adjectives and hedges are also mostly uttered by female characters in the movie. However, male characters also used the elements of female speech in their dialogues and we can see balanced usage of female speech elements by female and male characters in the movie. Walt Disney Company has made a major change in the production of movies and representation of female characteristics in the movie. This paper has provided insights into the revolution taken by Disney in producing modern princesses who represent new generations and are no longer portrayed as weak and powerless.

\section{References}

Do Rozario, R. C. (2004). The princess and the magic kingdom: Beyond nostalgia, the function of the Disney

Princess. Women's Studies in Communication, 27(1), 34-59.

England, D., Lara D., and Melissa C.M. (2011). Gender role portrayal and the Disney princesses. Sex

Roles, 64, 55-567.

Heritage, F. (2015). Disney princesses and the diachronic change of culturally gendered language. In P.Clements, A. Krause, \& H. Brown (Eds.), JALT2014 Conference Proceedings. Tokyo: JALT.

Hoerrner, K. L. (1996). Gender roles in Disney films: Analyzing behaviors from Snow White to Simba. Women's Studies in Communication, 19 (2), 213-228.

Holmes, J. (1995). Women, Men and Politeness. London: Longman Group.

Ismail, A. \& Yusof, N. (2016). Readability of ESL pictures book in Malaysia. Journal of Nusantara Studies,1 (1),60-70.

Lacroix, C. (2004). Images of animated others: The orientalization of Disney's cartoon heroines from the Little Mermaid to the Hunchback of Notre Dame. Popular Communication, 2 (4), 213- 229.

Lakoff, R. (1975). Language and women's place. New York: Harper and Row.

Law, M. (2014). Sisters doin'it for themselves: Frozen and the evolution of the Disney heroine. Screen Education, 1 (74), 16-25.

Rashid, R.A (2016). Topic continuation strategies employed by teachers in managing supportive conversations on Facebook Timeline. Discourse Studies, 18(2), 188-203.

Rashid, R.A, Yunus, K., Azmi, N. J., Rahman, S. B. A., \& Yusoff, S. Z. (2016). The discursive construction of teachers' desirable identity on a social networking site. International Journal of Applied Linguistics and English Literature, 5(5), 139-144.

Rashid, R.A, Rahman, M. F. A., \& Rahman, S. B. A. (2016).Teachers' engagement in social support process on a networking site. Journal of Nusantara Studies, 1(1), 34-45.

Saladino, C.J. (2014). Long may she reign: A rhetorical analysis of gender expectations in Disney's

Tangled and Disney/Pixar's Brave.(Unpublished doctoral dissertation). University of Nevada, Las Vegas.

Thompson, T. L., \& Zerbinos, E. (1995). Gender roles in animated cartoons: Has the picture changed in 20

years? Sex Roles, 32 (1), 651-673.

Velco, P.D. (Producer) \& Buck, C., Lee, J. (2013). Frozen [Motion Picture]. United States: Walt Disney 